RAZGLEDI

\title{
ODNOS DO TRAJNOSTNEGA RAZVOJA IN VIRI ZNANJA O TRAJNOSTNEM RAZVOJU ŠTUDENTOV GEOGRAFIJE V SLOVENIJI
}

\author{
AVTORJA \\ dr. Valentina Brečko Grubar \\ Univerza na Primorskem, Fakulteta za humanistične študije, Titov trg 5, SI - 6000 Koper, Slovenija \\ valentina.brecko.grubar@fhs.upr.si

\section{dr. Gregor Kovačič} \\ Univerza na Primorskem, Fakulteta za humanistične študije, Titov trg 5, SI - 6000 Koper, Slovenija \\ gregor.kovacic@fhs.upr.si
}

DOI: $10.3986 / G V 89105$

UDK: 91:37.061:502.131.1(497.4)

COBISS: 1.01

\section{IZVLEČEK}

Odnos do trajnostnega razvoja in viri znanja o trajnostnem razvoju študentov geografije $v$ Sloveniji Prispevek predstavlja rezultate raziskave o odnosu in virih znanja o trajnostnem razvoju (TR) študentov geografije na vseh treh javnih univerzah $v$ Sloveniji. Na spletno anketo je odgovorilo 175 študentov oziroma $34 \%$ populacije prvič vpisanih študentov geografije na prvi in drugi stopnji v študijskem letu 2016/2017. Dve tretjini študentov menita, da je njihova predstava o TR dobra. Tisti, ki višje vrednotijo lastno poznavanje TR, mu hkrati pripisujejo večji pomen in menijo, da so njegove vsebine bolj povezane s študijem. Rezultati kažejo, da znanje o trajnostnem razvoju večinoma pridobivajo s formalnim izobraževanjem, vendar pa nismo dokazali, da bi delež od začetka do zaključka študija statistično značilno naraščal. Pričakovano so, po mnenju študentov, med predmeti študijskih programovs TR najbolj povezani tisti, kjer je že iz imena predmeta pričakovati vsebine o TR. Največ različnih predmetov so navedli študenti Univerze v Ljubljani, najbolj enakomerno pa so navedbe razporedili študenti Univerze na Primorskem.

\section{KLJUČNE BESEDE}

geografija, trajnostni razvoj, anketiranje, izobraževanje, univerze, Slovenija

\begin{abstract}
Attitude towards sustainable development and sources of knowledge of sustainable development among geography students in Slovenia

The paper presents the results of the survey conducted among geography students of all three public universities in Slovenia regarding their attitude towards sustainable development (SD) and sources of knowledge of SD. 175 students or 34\% of the geography students population of first and second cycles in the study year 2016/2017 answered to online questionnaire. Two thirds of them assessed their knowledge of SD as good. Those, who assessed their knowledge of SD being higher, simultaneously think that SD is more important and that its contents is more incorporated into theirs' study. Students gained most of their respective knowledge through formal education. However, we have not proven that the ratio of knowledge gained by formal education statistically significant increases from the beginning to the end of the studies. Not surprisingly,
\end{abstract}


according to the students' opinion the greatest connectedness with the SD have those courses where it can be concluded from their names that they are strongly connected with the SD contents. The biggest list of different courses was reported by students of the University of Ljubljana, the most uniformly distributed list of different courses is characteristic for students of the University of Primorska.

\section{KEY WORDS}

geography, sustainable development, survey, education, universities, Slovenia

Uredništvo je prispevek prejelo 16. junija 2017. 


\section{Uvod}

Glede na vedno bolj opazne in uničujoče posledice človekovega bivanja in delovanja na Zemlji bi pričakovali, da bo trajnostnost kot paradigma in strategija za nujne spremembe v upravljanju sveta na okoljskem, socialno-kulturnem in gospodarskem področju že trdno zakoreninjena v učnih programih na vseh ravneh izobraževanja. Po mnenju Mlinarja (2011) pa smo od tega še precej oddaljeni. Med znanostmi o trajnostnem razvoju v splošnem prednjačijo okoljske znanosti in tehnologije (Nučič 2012). Toda geografija, kot presečna veda med naravoslovjem, družboslovjem in humanistiko, ima in bo imela tudi v prihodnje, zaradi utemeljene povezanosti interdisciplinarnosti in trajnostnosti (Jones, Selby in Sterling 2010), s svojim celostnim pogledom, širino in odprtostjo nedvomno pomembno vlogo pri izobraževanju za trajnostni razvoj (v nadaljevanju TR). V Sloveniji se je na tem področju uveljavila predvsem po zaslugi Pluta $(1998 ; 2005 ; 2006 ; 2008 ; 2010)$.

Preučevanje poznavanja in odnosa do TR je bilo cilj številnih raziskav (na primer Summers, Corney in Childs 2004; Kagawa 2007; Blum 2010; Catenazzo s sodelavci 2010; Incekara in Tuna 2011; Michalos s sodelavci 2011; Michalos s sodelavci 2012; Kovačič in Brečko Grubar 2012; 2016). V naši se osredotočamo na preučevanje odnosa študentov prve in druge stopnje geografije v Sloveniji do TR ter na povezavo med viri znanja o TR s predmetniki študijskih programov. Sorodna raziskava je bila izvedena že v študijskem letu 2011/2012 ( $n=160)$ (Kovačič in Brečko Grubar 2016), v katero pa študenti geografije druge stopnje, z izjemo študentov z Univerze na Primorskem, niso bili vključeni. S primerjavo izbranih rezultatov obeh raziskav smo želeli ugotoviti nastale razlike $v$ razmiku petih let. $S$ predhodno raziskavo (Kovačič in Brečko Grubar 2016) nismo mogli ugotoviti, kako so vsebine drugostopenjskih programov geografije $\mathrm{v}$ Sloveniji povezane $\mathrm{z}$ vsebinami TR, kako podiplomski študenti ocenjujejo lastno poznavanje in razumevanje TR, kakšen je njihov odnos do TR ter kakšen pomen pripisujejo posameznim oblikam izobraževanja za TR. Preverjali smo tudi, ali se je povezanost vsebin trajnostnega razvoja s študijskimi programi geografije v Sloveniji v obdobju med raziskavama okrepila. Za primerjavo smo uporabili tudi rezultate raziskave, opravljene leta 2011 med študenti treh fakultet Univerze na Primorskem $(n=238)$ (Kovačič in Brečko Grubar 2012).

\section{Podatki in metode}

Raziskava temelji na anketiranju študentov študijskih programov geografije prve in druge stopnje na treh javnih slovenskih univerzah. Za pridobivanje podatkov je bil uporabljen anonimni vprašalnik $\mathrm{s} 46$ vprašanji, izdelan $\mathrm{v}$ spletnem orodju $1 \mathrm{ka}$ (1KA 2016). Vprašanja so bila večinoma zaprtega tipa z enim ali več možnimi odgovori. V prispevku objavljamo rezultate analize vprašanj o odnosu do TR ter virih znanja o TR. Z namenom ugotavljanja povezanosti študijskih programov geografije $z$ vsebinami TR, smo študente zaprosili za navedbo do pet študijskih predmetov, ki si sledijo glede na zastopanost vsebin o TR. Zaradi zagotavljanja realnejših rezultatov (srečanje z več predmeti, ki jih lahko med seboj tudi primerjajo), smo analizirali zgolj odgovore študentov tretjega letnika prve ter študentov obeh letnikov druge stopnje.

Skupaj je bilo anketiranih 175 ali $34 \%$ populacije prvič vpisanih študentov geografije v jesenskem semestru študijskega leta 2016/2017. V raziskavi je sodelovalo $31 \%$ populacije študentov prve (prvi letnik $28 \%$, drugi letnik $31 \%$ in tretji letnik $34 \%$ ) in $36 \%$ (prvi letnik $43 \%$ in drugi letnik $29 \%$ ) populacije študentov druge stopnje. Na spletni vprašalnik je v celoti odgovorilo 107 študentk (64\%) in 59 študentov (36 \%); 65 \% anketiranih predstavljajo študenti prve stopnje. Na Univerzi na Primorskem (v nadaljevanju UP) je bilo na študijskih programih geografije anketiranih 33 študentov ali $64 \%$ populacije, od tega 14 deklet ( $42 \%$ ), na Univerzi v Mariboru (v nadaljevanju UM) je bilo anketiranih 22 študentov ali $21 \%$ populacije, od tega 20 deklet (91\%), in na Univerzi v Ljubljani (v nadaljevanju UL) 111 študentov ali $31 \%$ populacije, od tega 73 deklet (66\%); 9 anketirancev ni navedlo podatka o študijskem 
programu. Delež anketiranih študentov z UP od vseh anketiranih študentov za $10 \%$ presega delež, ki ga študenti geografije $\mathrm{z}$ UP predstavljajo $\mathrm{v}$ skupnem številu študentov geografije v Sloveniji, pri študentih z UM je ta delež $7 \%$ manjši in pri študentih geografije z UL približno enak. Reprezentativnost preučevanega vzorca je za obe stopnji študija in tudi glede zastopanosti študentov s posameznih univerz ustrezna.

Analiza odgovorov temelji na opisni in inferenčni statistiki preučevanih spremenljivk s pomočjo različnih statističnih postopkov. Uporabili smo programa Microsoft Office Excel 2010 in SPSS 21. Povezave med frekvencami odgovorov študentov geografije na posameznih univerzah, v posameznih letnikih in glede na spol s posameznimi vprašanji smo za imenske spremenljivke preučili s pomočjo Pearsonove $\chi^{2}$ statistike (Košmelj 2007). Jakost povezanosti opisnih spremenljivk smo preverjali s Cramerjevim koeficientom (V), ki je mera povezanosti, določena na intervalu 0 do 1 (Garson 2012). Največja statistična odstopanja $\mathrm{v}$ preučevanih kontingenčnih preglednicah, tudi v primerih, ko izračun $\chi^{2}$ statistike za celotno preglednico ni pokazal bistvenih odstopanj med posameznimi celicami, smo ugotavljali s pomočjo analize vrednosti prilagojenih ostankov. Vrednosti prilagojenega ostanka, večje od 2, pomenijo statistično značilno razliko $(\alpha<0,05)$, vrednosti, večje od 3, pa kažejo na močno odstopanje $(\alpha<0,01)$ (Agresti 2007; Komulainen 2016). Stopnjo povezanosti med pari urejenostnih spremenljivk smo preverjali s Spearmanovim korelacijskim koeficientom (Košmelj 2007). Za testiranje statistično značilnih razlik urejenostnih spremenljivk z dvojiškimi imenskimi spremenljivkami smo uporabili Mann Whitney U-test (Laerd ... 2017). Vrednosti s statistično značilnostjo večjo od $99 \%(\alpha=0,01)$ smo privzeli kot statistično značilen pojav in dopisali $p$-vrednosti.

\section{Rezultati}

\subsection{Odnos do TR}

Dve tretjini (67\%) študentov menita, da je njihova predstava o TR dobra in petina (21\%), da je slaba; lestvica je bila štiristopenjska, brez srednje možnosti. Če rezultate primerjamo z raziskavo, opravljeno med študenti geografije v študijskem letu 2011/2012 (Kovačič in Brečko Grubar 2016), ugotovimo, da se je za $14 \%$ povečal delež študentov, ki menijo, da imajo dobro predstavo o TR, in za enak odstotek zmanjšal delež tistih, ki menijo, da je njihova predstava o TR slaba. Zgolj $3 \%$ anketiranih je svoje poznavanje TR ocenilo kot zelo slabo in $9 \%$ kot zelo dobro. Med spolom in lastno predstavo o poznavanju TR ni statistično značilne povezanosti, razlike v deležih odgovorov pa so zanemarljive. Izračuni so tudi tokrat pokazali, da ni statistično značilne povezanosti med študenti geografije na posameznih univerzah in lastno predstavo o poznavanju TR, kar je bilo ugotovljeno že v predhodni raziskavi (Kovačič in Brečko Grubar 2016). Pri študentih z UP nekoliko izstopa večji delež odgovorov »slaba« (33\%, prilagojen ostanek $+1,8$ ), pri študentih z UM pa manjši delež odgovorov »slaba« ( $9 \%$, prilagojen ostanek -1,5). Predstava o lastnem poznavanju TR študentov geografije je statistično značilno nizko pozitivno povezana $\mathrm{z}$ letnikom študija $(\rho=0,249 ; p=0,0012)$; kot boljšo so svojo predstavo o TR ocenjevali študenti višjih letnikov. V kontingenčni preglednici med letniki študija in lastno predstavo o TR študenti prvih letnikov statistično močno odstopajo $\mathrm{z}$ velikim deležem v kategoriji »slaba« (prilagojeni ostanek $+3,2$ ), $\mathrm{z}$ manjšim deležem odgovorov od pričakovanih pa statistično značilno odstopajo tudi v kategoriji »dobra « (prilagojeni ostanek -2,9), vendar odstopanja niso tako velika, kot smo jih ugotovili v raziskavi v študijskem letu 2011/2012 (+3,3 in -5,6) (Kovačič in Brečko Grubar 2016). Študenti drugega letnika druge stopnje statistično značilno odstopajo $\mathrm{z}$ večjim deležem odgovorov v kategoriji »dobra« predstava o TR (prilagojeni ostanek +2,2). Kar $87 \%$ študentov druge stopnje ocenjuje lastno poznavanje TR kot »dobro« oziroma »zelo dobro«, kar je za četrtino več, kot je pokazala raziskava med podiplomskimi študenti na Oxfordski univerzi ( $n=61$; z $80 \%$ deležem so prevladovali študenti geografije) (Summers, Corney in Childs 2004) ter več kot raziskavi, opravljeni med študenti geografije 
v študijskem letu 2011/2012 in študenti treh fakultet UP v letu 2011 (Kovačič in Brečko Grubar 2012; 2016). Na podlagi navedenega lahko predvidevamo, da so vsebine o TR danes bolj prisotne v študijskih programih. Predstava o lastnem poznavanju TR študentov geografije je statistično značilno nizko pozitivno povezana $\mathrm{z}$ oceno povezanosti vsebin TR s študijskim programom $(\rho=0,312 ; p<0,0000)$ in z oceno pomena TR anketiranih študentov $(\rho=0,315 ; p<0,0000)$. Rezultati torej kažejo, da tisti, ki lastno poznavanje TR ocenjujejo kot boljše, hkrati TR pripisujejo večji pomen in višje ocenjujejo povezanost vsebin študijskih programov s TR.

Odnos študentov do TR smo preučevali s pomočjo opredeljevanja do trditev, na katere je bilo mogoče odgovarjati na petstopenjski letvici (od 1 - »zelo se ne strinjam« do 5 - »zelo se strinjam«). Predpostavljamo, da odnos do TR hkrati odraža tudi poznavanje in razumevanje TR v najširšem pomenu. Izračunane povprečne vrednosti pri trditvah in seštevek deležev odgovorov pri kategorijah 4 (»se strinjam«) in 5 (»zelo se strinjam«), razen pri trditvah 9, 10, 12, 14 in 16, kjer je prikazan seštevek deležev odgovorov pri kategorijah 1 ("zelo se ne strinjam«) in 2 (»se ne strinjam«) (skupaj in ločeno po univerzah), so prikazani v preglednici 1. Pričakovano so najnižje povprečne vrednosti zabeležene pri trditvah $9,10,12,14$ in 16, saj imajo obrnjeno mersko lestvico, pri ostalih trditvah pa povprečne vrednosti v glavnem presegajo 4 .

Rezultati kažejo (preglednica 1), da se študenti v pretežni meri zavedajo, da razdelitev dobrin na planetu ni pravična (povprečna vrednost je 1,5), hkrati pa presenečata nadpovprečna vrednost 3,1 pri trditvi 9 (»Neomejena gospodarska rast je združljiva z lajšanjem socialnih problemov in zmanjševanjem socialnih razlik«) in povprečna vrednost 2,5 pri trditvi 14 (»Trajnostni razvoj je možen v sožitju s prevladujočo paradigmo liberalnega kapitalizma, ki sloni na ustvarjanju dobička «). Oboje kaže na slabše poznavanje socialno-kulturnih in gospodarskih prvin TR ter na zaskrbljujoč učinek prevladujoče paradigme neoliberalnega kapitalizma na razmišljanje mladih ljudi. Tudi relativno visoko povprečje $(2,5)$ pri trditvi 16 (»Neomejena gospodarska rast je združljiva z ohranjanjem naravnih ravnovesij«) dokazuje nerazumevanje nekaterih osnovnih načel TR. Statistika $\chi^{2}$ kaže, da deleži odgovorov pri kategorijah posameznih trditev o odnosu do TR niso statistično značilno povezani z domicilno univerzo anketiranih študentov. Izjema je trditev $16(p=0,0065 ; V=0,252)$, kjer se kaže nizka statistična povezanost; izstopata večji delež odgovorov "zelo se ne strinjam« pri študentih UL (prilagojen ostanek $+2,5$ ) in manjši pri UP (prilagojen ostanek -2,8) ter ravno obratno pri kategoriji »zelo se strinjam « $(\mathrm{UL}-2,0$ in UP +2,9). V kontingenčnih preglednicah izstopajo še: pri trditvi 5 večji delež odgovorov »se strinjam« pri študentih UP (prilagojen ostanek +2,5), pri trditvi 9 manjši delež odgovorov "se ne strinjam " pri UM (prilagojen ostanek -2,1), pri trditvi 10 večji delež odgovorov »zelo se ne strinjam « pri UL $(+2,5)$ in manjši pri UM $(-2,2)$, večja deleža odgovorov »se strinjam « in "zelo se strinjam " pri UP $(+2,0$ in $+2,1)$ in pri trditvi 14 manjši delež »se strinjam « pri UL $(-3,0)$, kar kaže na boljše razumevanje in odnos do TR študentov z UL. Prilagojena ostanka $+3,8$ (UP) in $-2,2$ (UL) pri trditvi 12 v kategoriji »zelo se strinjam « kažeta na povsem nasproten odnos do smiselnosti udejstvovanja na področju varstva okolja; študenti UP so glede tega bolj pesimistični.

Statistika $\chi^{2}$ kaže, da pri študentih geografije v Sloveniji deleži odgovorov pri posameznih kategorijah na trditve o TR niso statistično značilno povezani s spolom, razen pri trditvah $6(p=0,0094$; $V=0,284)$ in $7(p=0,0053 ; V=0,298)$, kjer se kaže nizka statistična povezanost. Z Mann-Whitneyevim $U$ testom smo ugotovili, da je strinjanje s trditvami $1(p=0,0069), 3(p=0,0030)$ in $7(p=0,0008)$ statistično značilno bolj izraženo pri študentkah, medtem ko pri ostalih trditvah razlike med spoloma nismo dokazali.

Za večino trditev o TR velja, da $z$ letnikom študija niso statistično značilno povezane spremenljivke, nizka statistično značilna pozitivna povezanost $\mathrm{z}$ letnikom študija se kaže samo pri trditvah 2 $(\rho=0,220 ; p=0,0045), 7(\rho=0,278 ; p=0,0003)$ in $11(\rho=0,219 ; p=0,0045)$, kar pomeni, da študenti višjih letnikov izražajo večje strinjanje $z$ vključevanjem vsebin TR v izobraževanje, s pomembnostjo delovanja vsakega posameznika za doseganje skupnih ciljev TR in s potrebo spodbujanja trajnejše rabe dobrin. 
Preglednica 1: Povprečne vrednosti in delež odgovorov (\%) pri kategorijah »se strinjam « in »zelo se strinjam «, razen pri trditvah 9, 10, 12, 14 in 16, kjer je prikazan delež odgovorov pri kategorijah "zelo se ne strinjam " in "se ne strinjam", na trditve o trajnostnem razvoju (merska lestvica: 1 - zelo se ne strinjam do 5 - zelo se strinjam).

trditev / univerza UP UM UL skupaj $(n=33) \quad(n=22) \quad(n=111) \quad(n=166)$

1. Sedanja generacija mora zagotoviti, da bo naslednja generacija nasledila družbo, ki bo vsaj enako zdrava, $4,3 / 90 \quad 4,5 / 91 \quad 4,4 / 95 \quad 4,3 / 91$ raznolika in produktivna kot današnja.

2. Proizvajalci ne smejo spodbujati rabe stvari za enkratno uporabo.

3. Potrebujemo strožje zakone in predpise za zaščito okolja ter boljši nadzor nad njihovim izvajanjem.

4. Trajnostni razvoj ne bo mogoč, dokler bogate države ne bodo prenehale $\mathrm{z}$ izkoriščanjem naravnih virov in delovne sile manj razvitih držav.

5. Razvite države morajo prevzeti levji delež stroškov za odpravljanje posledic podnebnih sprememb na celotnem planetu.

6. Podjetja, ki so okoljsko odgovorna, imajo v prihodnosti $\quad 3,8 / 63 \quad 3,6 / 69 \quad 3,6 / 55 \quad 3,7 / 58$ boljše možnosti za povečanje dobičkov.

7. Učenje osnov trajnostnega razvoja mora biti vključeno $\quad 4,4 / 88 \quad 4,2 / 86 \quad 4,3 / 88 \quad 4,3 / 88$ $\mathrm{v}$ učne načrte vseh disciplin na vseh stopnjah izobraževanja.

\begin{tabular}{lllll}
\hline 8. Vlade morajo spodbujati rabo energetsko učinkovitejših & $4,7 / 100$ & $4,4 / 87$ & $4,5 / 95$ & $4,5 / 94$
\end{tabular} proizvodnih procesov in prevoznih sredstev.

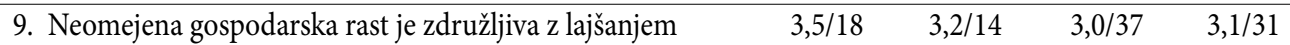
socialnih problemov in zmanjševanjem socialnih razlik.

\begin{tabular}{lllll}
\hline 10. Porazdelitev dobrin na planetu je pravična. & $1,8 / 84$ & $1,7 / 91$ & $1,4 / 96$ & $1,5 / 94$ \\
\hline 11. V trajnostnem razvoju je pomembno ravnanje vsakega & $4,5 / 88$ & $4,3 / 91$ & $4,3 / 94$ & $4,3 / 92$
\end{tabular} posameznika.

12. Vključevanje v okoljevarstvene zadeve ni smotrno, saj imajo vlade in gospodarstvo preveliko moč in lahko počnejo, kar hočejo.

13. Reševanje uničujočih posledic podnebnih sprememb $\quad 4,4 / 90 \quad 4,3 / 86 \quad 4,2 / 88 \quad 4,2 / 87$ (opustošenje posameznih pokrajin, izguba kmetijske zemlje, selitve ...) je treba reševati na planetarni ravni.

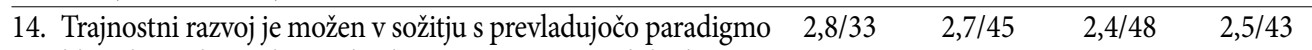
liberalnega kapitalizma, ki sloni na ustvarjanju dobička.

15. Za ohranitev ekološkega ravnovesja planeta je potrebno $\quad 4,2 / 88 \quad 4,0 / 82 \quad 4,0 / 82 \quad 4,1 / 82$ samoomejevanje in zmanjševanje koriščenja dobrin in energije v razvitem delu sveta.

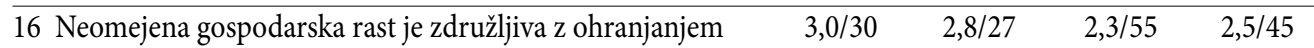
naravnih ravnovesij.

17. Davki na onesnaženje se morajo povečati zaradi poplačila $\quad 4,0 / 75 \quad 3,9 / 83 \quad 4,0 / 80 \quad 4,0 / 76$ škode družbi in okolju. 


\subsection{Viri znanja o TR}

Razveseljivo je dejstvo, da je 80 \% študentov odgovorilo pritrdilno na vprašanje, ali so se že učili o TR in pridobljeno znanje vpliva na njihov odnos do TR ter na vsakodnevne navade, kar je $18 \%$ več kot v raziskavi, opravljeni v študijskem letu 2011/2012 (Kovačič in Brečko Grubar 2016) in približno $10 \%$ več kot v raziskavi, opravljeni med študenti UP leto poprej (Kovačič in Brečko Grubar 2012). Več pritrdilnih odgovorov je bilo pri študentkah (84\%), toda spol in zgornja trditev nista statistično povezani spremenljivki. Enako kot je pokazala raziskava med študenti geografije v študijskem letu 2011/2012 (Kovačič in Brečko Grubar 2016), tudi ta raziskava kaže, da delež študentov, ki so se že učili o TR, narašča od začetka do zaključka študija (prvi letnik prve stopnje 58 \%, drugi letnik prve stopnje $61 \%$, tretji letnik prve stopnje $97 \%$, prvi letnik druge stopnje $100 \%$ in drugi letnik druge stopnje $87 \%$ ). Iz tega bi lahko tudi sklepali, da so vsebine TR primerno vključene v študijske programe geografije. Letnik in stopnja študija ter odgovori na vprašanje o učenju o TR sta zmerno statistično značilno povezani spremenljivki $(p<0,0000 ; V=0,465)$. Iz kontingenčne preglednice je razvidno močno statistično odstopanje navzdol pri pritrdilnih odgovorih v prvem (prilagojeni ostanek -4,5) in statistično značilno odstopanje $\mathrm{v}$ drugem letniku prve stopnje (prilagojeni ostanek -2,5) ter statistično značilno odstopanje navzgor pri tretjem letniku prve stopnje (prilagojeni ostanek $+2,9$ ) in močno odstopanje v prvem letniku druge stopnje (prilagojeni ostanek $+3,4)$. Tudi Mann-Whitneyev U test $(p<0,0000)$ kaže, da je večji delež pritrdilnih odgovorov statistično značilno bolj izražen pri višjih letnikih. $\mathrm{V}$ primerjavi $\mathrm{z}$ rezultati v študijskem letu 2011/2012 je občutno večji delež pritrdilnih odgovorov prvih letnikov prve stopnje (2011/2012 $30 \%$ ), iz česar bi lahko sklepali, da so vsebine o TR našle ustrezni prostor tudi v srednješolskih programih; za $10 \%$ je večji tudi delež pritrdilnih odgovorov med študenti tretjih letnikov prve stopnje (2011/2012 86 \%) (Kovačič in Brečko Grubar 2016), kar potrjuje že omenjeno domnevo, da se vsebinam o TR na študijskih programih geografije v Sloveniji v zadnjem obdobju posveča več pozornosti. Vprašanje o učenju o TR in domicilnost anketiranih nista statistično značilno povezani spremenljivki.

Za študente, ki so odgovorili, da so se že učili o TR, smo s pomočjo vnaprej ponujenih odgovorov ugotavljali, kaj je najpomembnejši vir pridobljenega znanja. Izbrali so lahko več odgovorov, navedenih v preglednici 2. Za študente geografije v Sloveniji je najpomembnejši vir znanja o TR »formalno izobraževanje« ( $20 \%$ vseh navedb), ki ga je izbralo kar $86 \%$ vseh, ki so se že učili o TR. Ta rezultat je primerljiv z rezultati raziskave, opravljene v študijskem letu 2011/2012, ko je formalno izobraževanje izbralo 82 \% študentov (Kovačič in Brečko Grubar 2016). To zopet kaže, da so vsebine o TR vključene tako v srednješolskem izobraževanju kot tudi na dodiplomskem in podiplomskem študiju geografije. Delež navedb je za odstotek manjši kot v raziskavi med študenti UP v letu 2011 (Kovačič in Brečko Grubar 2012), delež študentov v kategoriji »formalno izobraževanje« pa je za 5 \% večji od izračunanega za podiplomske študente geografije na Oxfordski univerzi (Summers, Corney in Childs 2004). Med anketiranimi dijaki v kanadski provinci Manitoba jih je zgolj $14 \%$ navedlo, da so se o TR že učili v okviru formalnega izobraževanja (Michalos s sodelavci 2011). Od drugega do četrtega mesta si sledijo kategorije »dokumentarni programi ...« (izbralo ga je $67 \%$ študentov, $16 \%$ vseh navedb), »strokovna in znanstvena literatura « (57\% študentov, $13 \%$ vseh navedb), »spletne strani, forumi ... « (55\% študentov, $13 \%$ vseh navedb) in »časopisje in revije « ( $46 \%$ študentov, $11 \%$ vseh navedb). Pri vseh treh kategorijah so deleži navedb in študentov za nekaj odstotnih točk večji, kot so bili ugotovljeni v raziskavi, opravljeni v študijskem letu 2011/2012 (Kovačič in Brečko Grubar 2016). Statistično značilnih odstopanj pri deležih navedb posameznih odgovorov o virih znanja o TR med študijskimi programi geografije na vseh treh univerzah ni, medtem ko je predhodna raziskava, opravljena v letu 2011/2012, pokazala statistično značilna odstopanja pri nekaterih odgovorih; pri »formalno izobraževanje« je v negativno smer odstopala UP, pri »okolica ... « pa UL v negativno in UP v pozitivno smer (Kovačič in Brečko Grubar 2016).

Najmanj študentov je kot vir znanja o TR navedlo »neformalno izobraževanje« (6-9\% vseh navedb), ki obsega udejstvovanje študentov na tečajih, krožkih, delavnicah in okroglih mizah zunaj študijskega procesa. Delež je povsem enak kot v raziskavi iz leta 2011/2012 (Kovačič in Brečko Grubar 2016). Razlog 
Preglednica 2: Deleži navedb (\%) posameznih odgovorov o virih znanja o TR ter deleži študentov (\%), ki so navedli posamezne odgovore o virih znanja o TR (izbrati je bilo mogoče več odgovorov).

\begin{tabular}{lcccc}
\hline $\begin{array}{l}\text { odgovor / univerza } \\
(n \text { pri navedbah; } n \text { pri študentih) }\end{array}$ & $\begin{array}{c}\mathrm{UP} \\
(n=131 ; 28)\end{array}$ & $\begin{array}{c}\mathrm{UM} \\
(n=82 ; 20)\end{array}$ & $\begin{array}{c}\mathrm{UL} \\
(n=355 ; 85)\end{array}$ & $\begin{array}{c}\text { skupaj } \\
(n=568 ; 133)\end{array}$ \\
\hline $\begin{array}{l}\text { formalno izobraževanje } \\
\begin{array}{l}\text { neformalno izobraževanje } \\
\text { (tečaji, okrogle mize, društva, krožki ...) }\end{array}\end{array}$ & $16 / 75$ & $21 / 85$ & $21 / 89$ & $20 / 86$ \\
\hline $\begin{array}{l}\text { okolica (prijatelji, družina ...) } \\
\text { informativni programi TV, radio }\end{array}$ & $13 / 43$ & $7 / 30$ & $6 / 25$ & $7 / 29$ \\
\hline dokumentarni programi TV, radio & $11 / 50$ & $6 / 25$ & $10 / 44$ & $10 / 44$ \\
\hline časopisje in revije & $16 / 75$ & $16 / 65$ & $15 / 65$ & $16 / 67$ \\
\hline $\begin{array}{l}\text { strokovna in znanstvena literatura } \\
\text { (knjige, članki v revijah) }\end{array}$ & $12 / 57$ & $10 / 40$ & $10 / 44$ & $11 / 46$ \\
\hline spletne strani, forumi, akcije ... & $11 / 50$ & $17 / 70$ & $14 / 56$ & $13 / 57$ \\
\hline drugo & $11 / 50$ & $16 / 65$ & $13 / 54$ & $13 / 55$ \\
\hline
\end{tabular}

vidimo v tem, da so mladim bližje druge oblike pridobivanja informacij, povezane s sodobnimi mediji, čeprav so tudi deleži navedb pri "klasičnih medijih « večji kot v kategoriji neformalno izobraževanje. Opazna je tudi razlika v izbiri pri kategorijah »informativni programi« (9\% vseh navedb) in »dokumentarni programi« (16\% vseh navedb), kar lahko kaže dvoje; da mladi manj spremljajo informativne programe, ali pa da vsebine o TR ne najdejo ustreznega mesta v oddajah informativnega značaja.

Spremenljivki viri znanja o TR ter letnik in stopnja študija nista statistično značilno povezani. Enako velja, da deleži izbire posameznih odgovorov o virih znanja o TR med spoloma statistično značilno ne odstopajo. Povzetek analize odgovorov na vprašanje o virih znanja o TR kaže na zelo pomembno vlogo izobraževalnega sistema pri prizadevanju za ustvarjanje boljše skupne prihodnosti po načelih TR in izpostavlja odgovornost učiteljev v tej smeri na vseh ravneh izobraževanja. Pomen izobraževanja mladih o TR za doseganje njegovih svetovnih ciljev izpostavljajo tudi nekatere raziskave (Wade 1999; Catenazzo s sodelavci 2010).

\subsection{Povezanost vsebin TR s študijskimi programi geografije}

Kar $41 \%$ študentov meni, da so vsebine o TR srednje povezane s študijskimi programi geografije, kar je približno 7 \% več, kot je bilo ugotovljeno v predhodni raziskavi (Kovačič in Brečko Grubar 2016). Za približno enak odstotek je v pričujoči raziskavi, v primerjavi s predhodno, manjši delež tistih, ki menijo, da je povezanost vsebin TR s študijskimi programi geografije »velika« ali »zelo velika«. Drugače kot v raziskavi v študijskem letu 2011/2012 (Kovačič in Brečko Grubar 2016) statistično značilne povezanosti med povezanostjo študijskih vsebin s TR in domicilnostjo anketiranih študentov nismo ugotovili. V preglednici 3 so v odgovorih študentov iz posameznih univerz opazne nekatere razlike, ki pa niso statistično značilne. V kategoriji »srednja « $\mathrm{z}$ večjim deležem $(55 \%)$ in v kategorijah »velika« in »zelo velika « $\mathbf{z}$ manjšim deležem (skupaj 30 \%) odgovorov izstopajo študenti UP, UL pa z večjim deležem v kategoriji »zelo velika« (14\%).

Spremenljivki spol in povezanost vsebin TR s študijskimi programi geografije v Sloveniji nista statistično značilno povezani. Prav tako nismo ugotovili statistično značilne povezanosti med spremenljivkama letnik in stopnja študija ter povezanost vsebin TR s študijskimi programi geografije 
Preglednica 3: Povezanost vsebin TR s študijskimi programi geografije v Sloveniji (deleži odgovorov v \%).

\begin{tabular}{lcccc}
\hline odgovor / univerza & $\begin{array}{c}\text { UP } \\
(n=33)\end{array}$ & $\begin{array}{c}\text { UM } \\
(n=22)\end{array}$ & $\begin{array}{c}\text { UL } \\
(n=111)\end{array}$ & $\begin{array}{c}\text { skupaj } \\
(n=166)\end{array}$ \\
\hline zelo majhna & 3 & 0 & 3 & 2 \\
majhna & 12 & 14 & 14 & 14 \\
srednja & 55 & 41 & 38 & 31 \\
velika & 24 & 36 & 33 & 11 \\
zelo velika & 6 & 9 & 14 & \\
\hline
\end{tabular}

v Sloveniji, kar smo sicer ugotovili v raziskavi, opravljeni v študijskem letu 2011/2012 (Kovačič in Brečko Grubar 2016), ko se je pri študentih prvega letnika prve stopnje pokazalo močno statistično odstopanje pri kategoriji »zelo majhna povezanost «. Kontingenčna preglednica aktualne raziskave pokaže statistično značilno odstopanje pri prvem letniku prve stopnje pri odgovoru »zelo malo« (prilagojeni ostanek $+2,1)$, statistično značilno negativno odstopanje pri drugem letniku druge stopnje pri odgovoru »srednje ( prilagojeni ostanek -2,1) in statistično značilno negativno odstopanje pri drugem letniku prve stopnje pri odgovoru »veliko« (prilagojeni ostanek -2,5). Razlike v odgovorih o povezanosti vsebin TR s študijskimi programi med letniki in stopnjo študija prikazuje preglednica 4 . Spremenljivka povezanost vsebin TR s študijskimi programi geografije v Sloveniji je nizko statistično značilno pozitivno povezana $\mathrm{z}$ oceno lastne predstave anketiranih študentov o poznavanju $\operatorname{TR}(\rho=0,312 ; p<0,0000)$ in oceno pomembnosti TR za anketirane študente $(\rho=0,284 ; p=0,0002)$. To pomeni, da študenti, ki so lastno poznavanje TR ocenili kot boljše, TR pripisujejo večji pomen in menijo, da so vsebine TR bolj povezane s študijskim programom geografije, ki ga obiskujejo.

Z namenom ugotavljanja povezanosti študijskih programov geografije $\mathrm{z}$ vsebinami TR smo študente zaprosili za navedbo do pet študijskih predmetov, ki si sledijo po zastopanosti vsebin o TR. Vsebin učnih načrtov nismo pregledovali, smo pa morali preverjati imena predmetov, ker so študenti navajali predmete $\mathrm{z}$ nepopolnimi ali celo nepravilnimi imeni. V nadaljnjo analizo smo vključili prve tri navedene predmete, ker četrtega oziroma petega predmeta številni študentje niso navedli. Skupno število navedenih predmetov se je zmanjšalo že od prvo do tretje navedenih. Opozoriti moramo tudi na velike razlike v številu navedenih predmetov. Študenti UL so v nabor prvih treh navedli skupaj 29 različnih predmetov, študenti UP 18 in študenti UM 16 predmetov. Nekateri predmeti na drugi stopnji študija so iz nabora izpadli, čeprav bi iz imena predmeta pričakovali povezanost s TR. Razlog je verjetno $\mathrm{v}$ tem, da se študenti $\mathrm{z}$ njimi še niso srečali, na primer predmet se izvaja $\mathrm{v}$ pomladnem semestru 2. letnika, anketiranje pa je poteklo v začetku jesenskega, ali pa, da vsebin predmetov ne poznajo zaradi cikličnega izvajanja na UP. Predmeti, ki so po mnenju anketiranih študentov najbolj povezani

Preglednica 4: Povezanost (deleži odgovorov v \%) vsebin TR s študijskimi programi geografije v Sloveniji po letnikih in stopnji študija.

\begin{tabular}{lccccc}
\hline letnik in stopnja/odgovor & zelo malo & malo & srednje & veliko & zelo veliko \\
\hline 1. letnik - prva stopnja & 6 & 15 & 50 & 23 & 6 \\
2. letnik - prva stopnja & 0 & 26 & 48 & 9 & 17 \\
3. letnik - prva stopnja & 0 & 11 & 42 & 36 & 11 \\
1. letnik - druga stopnja & 3 & 8 & 39 & 39 & 11 \\
2. letnik - druga stopnja & 0 & 13 & 22 & 48 & 17 \\
\hline
\end{tabular}


s TR, so navedeni v preglednici 5. Rezultate smo primerjali z rezultati predhodne raziskave v študijskem letu 2011/2012 (Kovačič in Brečko Grubar 2016), pri čemer moramo upoštevati, da se je izvajanje študija na drugi stopnji takrat šele začelo, nekaj sprememb pa so doživeli tudi študijski programi na prvi stopnji.

Študenti geografije na UP so kot predmet, povezan s TR, največkrat navedli Trajnostno upravljanje z vodnimi viri, ki je predmet na drugi stopnji študija (13\%), sledila je Hidrogeografija in geografija morij (10\%) na prvi stopnji, nato pa šest predmetov z enakim deležem (7\%), štirje na prvi in dva na drugi stopnji. V predhodni raziskavi v študijskem letu 2011/2012 je prvo mesto pripadlo Uvodu v družbeno geografijo (23\%), sledili pa so Uvod v fizično geografijo (13\%) in na tretjem mestu Regionalna geografija sveta ter Pokrajinska in humana ekologija (10\%). Osem navedenih predmetov je dobilo $64 \%$ vseh omemb, kar je manj v primerjavi s predhodno raziskavo, ko je sedmim predmetom pripadlo $74 \%$. Kot prvo izbiro so študenti največkrat navedli Uvod v družbeno geografijo, kot drugo z enakim deležem Hidrologijo in ekologijo krasa ter Ekonomsko in socialno geografijo, kot tretjo izbiro pa zopet $\mathrm{z}$ enakim deležem Hidrogeografijo in geografijo morij ter Razvojne izzive na krasu.

Preglednica 5: Deleži navedb (\%) posameznih predmetov študijskih programov Geografije 1. in 2. stopnje, ki po mnenju študentov obravnavajo teme, povezane s TR.

\begin{tabular}{lll} 
univerza in predmet $\quad$ tip predmeta & stopnja $\quad$ delež navedb (\%) \\
\hline
\end{tabular}

\section{UNIVERZA NA PRIMORSKEM}

\begin{tabular}{llcc}
\hline Trajnostno upravljanje z vodnimi viri & obvezni & 2 & 13 \\
Hidrogeografija in geografija morij & obvezni & 1 & 10 \\
Geografija poselitve in prebivalstva & obvezni & 1 & 7 \\
Uporabna družbena geografija & izbirni & 1 & 7 \\
Uvod v družbeno geografijo & obvezni & 1 & 7 \\
Uporabna geografija v regionalnem razvoju & izbirni & 1 & 7 \\
Geografija globalizacije in marginalnih območij & obvezni & 2 & 7 \\
Hidrologija in ekologija krasa & izbirni & 2 & 7 \\
\hline UNIVERZA V MARIBORU & & & 18 \\
\hline Ekološka geografija & obvezni & 1 & 16 \\
Ekonomska geografija & obvezni & 1 & 9 \\
Sonaravno urejanje voda & izbirni & 1 & 9 \\
Ekoremediacije & obvezni & 2 & 7 \\
Socio-ekonomske strukture slovenskih pokrajin & obvezni & 1 & 7 \\
Hidrogeografija & obvezni & 1 & 7 \\
Vseživljenjsko izobraževanje za trajnostnost & obvezni & 2 & \\
Trajnostni razvoj zavarovanih območij & izbirni & 2 & 19 \\
\hline UNIVERZA V LJUBLJANI & & & 18 \\
\hline Geografija sonaravnega razvoja & izbirni & 1 & 16 \\
Ekološka geografija & obvezni & 1 & 13 \\
Humana ekologija & izbirni & 1 & 5 \\
Geografija okoljskih virov & obvezni & 2 & 3 \\
Geografija turizma in prometa & obvezni & 1 & 3 \\
Hidrogeografija & obvezni & 1 & 3 \\
Geografija Slovenije & obvezni & 1 & \\
Fizična geografija II & obvezni & 1 & \\
\hline
\end{tabular}


V predhodni raziskavi sta bili kot prvo izbrani Pokrajinska in humana ekologija ter Uvod v fizično geografijo, kot drugo Uvod v družbeno geografijo in kot tretje Regionalna geografija sveta.

Med prvimi tremi od petih predmetov, ki so jih, kot najbolj povezane s TR, navedli študenti geografije na UM, so največji delež omemb dobili: Ekološka geografija (18\%), Ekonomska geografija (16\%) ter na tretjem mestu Sonaravno urejanje voda in Ekoremediacije z enakim deležem ( $9 \%)$. Prvi trije so predmeti prve stopnje študija, na drugi stopnji pa je, po mnenju anketiranih, s TR najbolj povezan predmet Ekoremediacije. V predhodni raziskavi v študijskem letu 2011/2012 je prvo mesto pripadlo predmetu Sonaravno urejanje voda (32\%), sledili pa sta Varovanje prsti (17\%) in Hidrogeografija (15\%). Osem navedenih predmetov je dobilo $78 \%$ vseh navedb in, kot je razvidno iz preglednice 5 , so se navedbe bolj enakomerno razporedile med več predmetov. Prvim štirim sledijo namreč štirje predmeti z enakim deležem, dva na prvi in dva na drugi stopnji študija. Kot prvo izbiro so študenti geografije na UM največkrat navedli Ekonomsko geografijo, kot drugo izbiro enakovredno Ekonomsko geografijo, Ekološko geografijo ter Ekoremediacije in kot tretjo izbiro zopet Ekološko geografijo. V predhodni raziskavi je bil med prvo navedenimi izrazito v ospredju predmet Sonaravno urejanje voda, med drugo navedenimi enakovredno Hidrogeografija in Varovanje prsti ter med tretje navedenimi Varovanje prsti.

Študenti geografije na UL so kot prve tri možnosti največkrat navedli Geografijo sonaravnega razvoja (19\%), Ekološko geografijo (18\%) in Humano ekologijo (16\%). V raziskavi v študijskem letu 2011/2012 je prvo mesto pripadlo Hidrogeografiji (17\%), nato pa sta sledili zgoraj navedeni Geografija sonaravnega razvoja in Ekološka geografija. Med predmeti na drugi stopnji študija je po mnenju anketiranih s TR najbolj povezana Geografija okoljskih virov. Prvim štirim navedenim predmetom je pripadlo $67 \%$, osmim navedenim v preglednici 5 pa skupaj $81 \%$. V študijskem letu 2011/2012 je sedmim navedenim predmetom pripadlo $76 \%$ odgovorov. Śtudenti geografije na UL so kot prvo izbrani predmet največkrat navedli Geografijo sonaravnega razvoja (44\%), kar je več kot pri predhodni raziskavi (35\%), kot drugo izbrani predmet so navedli Humano ekologijo $(30 \%)$ in kot tretje izbrani pa Geografijo okoljskih virov (18\%). V predhodni raziskavi je bila kot drugo izbrana najpogosteje navedena Ekološka geografija (23\%) in kot tretje izbrana Humana ekologija (18 \%).

\section{Sklep}

Rezultati raziskave o poznavanju in odnosu do TR, izvedeni v študijskem letu 2011/2012, so bili zanimivi, vendar študentov geografije druge stopnje skoraj nismo mogli vključiti, saj so bili vpisani le na UP. Po petih letih smo zato želeli preveriti, ali je prišlo na področju vključevanja vsebin TR v študijske programe geografije v Sloveniji do sprememb. Ko smo ob prvi raziskavi pregledovali predmetnike druge stopnje, smo ugotovili, da so v njih precej bolj zastopani predmeti, povezani s TR, če sklepamo zgolj iz imen predmetov. Učnih načrtov namreč nismo pregledovali. Pričakovali smo torej, da bosta lastna ocena poznavanja in razumevanje TR med študenti druge stopnje študija opazno boljša, da bodo ti TR ocenili kot bolj pomemben in povezan s študijskim programom oziroma, da bodo večji pomen pripisali formalnemu izobraževanju. Pričakovanja so se v veliki meri uresničila. Kar 87 \% študentov druge stopnje ocenjuje lastno poznavanje TR kot »dobro« oziroma "zelo dobro", v primerjavi z raziskavo v študijskem letu 2011/2012 pa se je zvišal tudi delež študentov prve stopnje, ki imajo enako mnenje o svojem poznavanju TR. Med spolom in lastno predstavo o poznavanju TR ni statistično značilne povezanosti, prav tako ni statistično značilne povezanosti med študenti geografije na posameznih univerzah in lastno predstavo o poznavanju TR. V nadaljevanju smo ugotovili, da tisti, ki lastno poznavanje TR ocenjujejo kot boljše, hkrati TR pripisujejo večji pomen in višje ocenjujejo povezanost vsebin študijskih programov s TR. Analiza razumevanja načel TR, na podlagi strinjanja oziroma nestrinjanja s trditvami, je pokazala boljše razumevanje povezanosti TR z okoljem, slabše pa z gospodarskim in socialno-kulturnim poljem TR. Razlik med študenti različnih univerz nismo opazili, nekoliko boljše poznavanje pa so pokazali študenti UL. Študenti višjih letnikov se v večji meri strinjajo z vključevanjem 
vsebin TR v izobraževanje, s pomembnostjo posameznikovega delovanja za doseganje skupnih ciljev TR ter s trajnejšo rabo dobrin, ki zajema omejevanje proizvodnje dobrin za enkratno uporabo in njihovo ponovno uporabo. Za večino trditev o TR velja, da $z$ letnikom študija niso statistično značilno povezane spremenljivke, prav tako tudi ne s spolom. Na vprašanje o učenju o TR je kar $80 \%$ študentov odgovorilo pozitivno in menijo, da pridobljeno znanje vpliva na njihov odnos do TR ter na vsakodnevne navade. To je $18 \%$ več kot v raziskavi v študijskem letu 2011/2012 (Kovačič in Brečko Grubar 2016). Z višjim deležem pritrdilnih odgovorov izstopajo študenti tretjega letnika prve stopnje in študenti druge stopnje, $v$ primerjavi s predhodno raziskavo se je povečal tudi delež pritrdilnih odgovorov pri študentih na začetku študija. Učenje o TR kaže statistično značilno zmerno povezanost $z$ letnikom študija. Za poznavanje TR je še vedno najpomembnejše formalno izobraževanje, kar je podobno kot pri predhodni raziskavi (Kovačič in Brečko Grubar 2016) in glede na napredek pri poznavanju TR lahko sklepamo, da TR pridobiva na vključenosti na vseh ravneh izobraževanja. Pri pridobivanju znanja o TR pomembno vlogo ohranjajo izobraževalne oziroma dokumentarne oddaje, spletni mediji, najmanj pomembno pa je neformalno izobraževanje. Največ študentov geografije je menilo, da je njihov študijski program »srednje povezan « s TR, malo pa je tistih, ki menijo, da »ni povezan« ali da je »zelo povezan«. Iz rezultatov te in predhodne raziskave sklepamo, da študij geografije na vseh treh univerzah posveča precej pozornosti TR, saj je opazen napredek. Upamo lahko, da bo z znanjem diplomantov $\mathrm{v}$ večji meri zaživel tudi v praksi.

Zahvala: Zahvaljujemo se vsem študentom geografije, ki so odgovorili na spletni vprašalnik, ter kolegom učiteljem vseh treh univerz, ki so študente spodbujali $k$ izpolnjevanju ankete.

\section{Viri in literatura}

1KA, Odprtokodna aplikacija za spletno storitev anketiranja. Center za družboslovno informatiko Fakultete za družbene vede Univerze v Ljubljani. Ljubljana, 2016. Medmrežje: https://www.1ka.si/ (28. 10. 2016). Agresti, A. 2007: An Introduction to Categorical Data Analysis. New York.

Blum, A. 2010: Students' knowledge and beliefs concerning environmental issues in four countries. The Journal of Environmental Education 18-3. DOI: https://doi.org/10.1080/00958964.1987.9942734

Catenazzo, G., Epalle, A., Fragnière, E., Tuberosa, J. 2010: Testing the impact of sustainable development policies in Canton Geneva. Management of Environmental Quality 21-6. DOI: https://doi.org/ $10.1108 / 14777831011077682$

Garson, G. D. 2012: Measures of Association. Asheboro.

Incekara, S., Tuna, F. 2011: Attitudes of secondary school students towards environmental and sustainable development issues: A case study from Turkey. African Journal of Biotechnology 10-1. DOI: https://doi.org/10.5897/AJB10.012

Jones, P., Selby, S., Sterling, S. 2010: Sustainability Education: Perpectives and Practice Across High Education. London.

Kagawa, F. 2007: Dissonance in students' perceptions of sustainable development and sustainability: Implications for curriculum change. International Journal of Sustainability in Higher Education 8-3. DOI: https://doi.org/10.1108/14676370710817174

Komulainen, E. 2016: Analysing Tables, Part V, Interpreting Chi-Square. Medmrežje: http://www.helsinki.fi/ $\sim$ komulain/Tilastokirjat/09.\%20Ristiintaulukko.pdf (20.1.2016).

Košmelj, K. 2007: Uporabna statistika. Medmrežje: http://www.bf.uni-lj.si/agronomija/o-oddelku/ katedrein-druge-org-enote/za-genetiko-biotehnologijo-statistiko-in-zlahtnjenje-rastlin/statistika/ uporabnastat-2007.html (12.1.2017).

Kovačič, G., Brečko Grubar, V. 2012: Razumevanje trajnostno sonaravnega razvoja študentov Univerze na Primorskem. Iluzija ločenosti: ekološka etika medsebojne soodvisnosti. Koper. 
Kovačič, G., Brečko Grubar V. 2016: Knowledge of sustainable development among geography students in Slovenia. Acta geographica Slovenica 56-1. DOI: https://doi.org/10.3986/AGS.1633

Laerd Statistics: Mann-Whitney U Test Using SPSS Statistics. 2017. Medmrežje: https://statistics.laerd.com/ spss-tutorials/mann-whitney-u-test-using-spss-statistics.php (30.1.2017).

Michalos, A. C., Creech, H., McDonald, C., Hatch Kahlke, P. M. 2011: Measuring knowledge, attitudes and behaviours towards sustainable development: Two exploratory studies. Social Indicators Research 100-3. DOI: https://doi.org/10.1007/s11205-010-9620-9

Michalos, A. C., Creech, H., Swayze, N., Maurine Kahlke, P., Buckler, C., Rempel, K. 2012: Measuring knowledge, attitudes and behaviours concerning sustainable development among tenth grade students in Manitoba. Social Indicators Research 106-2. DOI: https://doi.org/10.1007/s11205-011-9809-6

Mlinar, A. 2011: Trajnost in univerza: možnosti, retorika, resničnost. Koper.

Nučič, M. 2012: Is sustainability science becoming more interdisciplinary over time? Acta geographica Slovenica 52-1. DOI: https://doi.org/10.3986/AGS52109

Plut, D. 1998: Varstvo geografskega okolja. Ljubljana.

Plut, D. 2005: Teoretična in vsebinska zasnova trajnostno sonaravnega napredka. Dela 23. DOI: https://doi.org/10.4312/dela.23.2.59-113

Plut, D. 2006: Mesta in sonaravni razvoj. Geografske razsežnosti in dileme urbanega sonaravnega razvoja. Ljubljana.

Plut, D. 2008: Vrednotenje geografskega okolja in okoljska etika. Dela 29. DOI: https://doi.org/10.4312/ dela.29.5.63-75

Plut, D. 2010: Geografija sonaravnega razvoja. Ljubljana.

Summers, M., Corney, G., Childs, A. 2004: Students teachers' conceptions of sustainable development: the starting-point of geographers and scientists. Educational Research 46-2. DOI: https://doi.org/ $10.1080 / 0013188042000222449$

Wade, J.A. 1999: Students as environmental change agents. International Journal of Contemporary Hospitality Management 11-2. DOI: https://doi.org/10.1108/09596119910272801

\section{Summary: Attitude towards sustainable development and sources of knowledge of sustainable development among geography students in Slovenia}

(translated by Gregor Kovačič)

The research is based on a survey conducted among geography students at the three Slovenian public universities in the study year 2016/2017. Included in the survey were students of the first-level university and the second-level master's study programmes of geography at the Faculty of Humanities, University of Primorska (hereafter UP), the Faculty of Arts, University of Maribor (hereafter UM), and the Faculty of Arts, University of Ljubljana (hereafter UL). The total number of students included in the survey was 175 , or $34 \%$ of geography students population at the first- and second levels in Slovenia in the study year 2016/2017; 65\% of respondents were students at the first level and 35\% were students at the second level. The sample of the investigated students at both levels of study is adequate and considered representative. The survey at the UP included 33 students of geography study programmes, or $64 \%$ of the population; at the UM, 22 students, or $21 \%$ of the population; and the survey at the UL included 111 students, or $31 \%$ of the population (166 fully completed questionnaires).

The online survey consisted of 46 questions; however, published in the current paper are only the results of descriptive and inferential statistics related to the students' attitude towards sustainable development (hereafter SD) and sources of students' knowledge about SD, and questions regarding connectedness of geography study programs with the SD contents. We compared results of this study with the results of similar research performed among the students of the three UP faculties $(n=238)$ 
in the year 2011 (Kovačič and Brečko Grubar 2012) and a similar research conducted among geography students $(n=160)$ at the three Slovenian public universities in the study year 2011/2012 (Kovačič and Brečko Grubar 2016). We used several statistical parameters to describe relationship between different types of variables (Pearson's $\chi^{2}$, Cramer's V, Spearman's $\rho$, Mann-Whitney U-test); furthermore, we performed analysis of adjusted residuals in different contingency tables. The statistical significance of calculated parameters was verified at a confidence interval of $99 \%(\alpha=0.01)$.

Two-thirds (67\%) of the respondents believe that their knowledge about SD is good, and $21 \%$ believe that their knowledge is poor. There was no option of answering "medium « to this question. The percentage of those geography students who assessed their knowledge of SD as very poor is low, 3\%, while $9 \%$ of the students believe that they have a very good knowledge of SD. The results show ( $\rho=0,249$; $p=0.0012$ ) that the notion of one's own knowledge about SD among Slovenian geography students is closely related to the year of study; students in higher classes assessed their knowledge of SD as being better. The students' own assessment of knowledge of SD is statistically significant low positively correlated to the assessment of connectedness of geography study programs with the SD contents $(\rho=0.312 ; p<0.0000)$ and to assessment of the importance of SD $(\rho=0.315 ; p<0.0000)$. Results show that those, who assessed their knowledge of SD being higher, simultaneously think that SD is more important and that its contents is more incorporated into theirs' study.

Students' attitude towards SD was studied based on students' declaration to seventeen five level Likert-type statements about SD, ranging from »strongly disagree« to »strongly agree«. We presume that attitude towards SD at the same time reflects the knowledge and understanding of SD in the broadest sense. The analysis of students' understanding of SD principles showed better understanding of connectedness of SD with the environmental part and worse with the economic and social parts of SD. We did not notice differences between the universities; somewhat better in comparison to others was the understanding of SD among the geography students from UL. Students in higher classes mostly agree: (1) with the integration of SD content into educational process, (2) importance of individual action for achieving common SD goals and (3) with the sustainable use of goods. The chi-square statistic shows that ratios of answers within different categories of individual statements about attitude towards SD are not statistically significant correlated to domicile university of respondents, nor with the gender. However, the exceptions are statements 6 (see Table 1): „Companies that are more environmentally responsible have better options for increasing their profit in the future $(p=0.0094 ; V=0.284)$ and 7 : "Learning of basis of SD should be incorporated in syllabuses of all disciplines in the entire educational vertical « $(p=0.0053 ; V=0.298)$, where weak correlation with gender is present. Using Mann-Whitney U-test, we conducted that the declaration to statements 1: "Present generation must ensure that next generation will inherit equally healthy, diverse and productive society as nowadays one « $(p=0.0069)$; 3: »We need more stringent laws and provisions for environmental protection and better surveillance of the implementation of the provisions « $(p=0.0030)$; and $7(p=0.0008)$ is statistically more expressed at female students, while at the other statements no differences showed. The majority of the statements show no correlation with the year of the study. Statistically significant low positive correlation with the year of study is characteristic only for the statements 2:»Producers must not encourage the production of non-reusable goods $(\rho=0.220 ; p=0.0045) ; 7(\rho=0.278 ; p=0.0003)$ and 11 : »In SD action of each individual counts « $(\rho=0.219 ; p=0.0045)$. These results imply that students of higher classes more agree: (1) with the incorporation of SD contents into educational process, (2) with the importance of action of each individual for accomplishing common SD goals and (3) with the need for encouraging of sustainable usage of goods.

The following two questions were related to the education about SD and the principal sources of knowledge, which influenced the students' insight into SD. The answers show that $80 \%$ of geography students have already received some education about SD. The percentage of geography students who have already been taught about SD is $18 \%$ higher than in the study conducted in study year 2011/2012 (Kovačič and Brečko Grubar 2016). The percentage of geography students who have already been taught 
about SD increases from the start of the undergraduate studies to the completion of postgraduate studies. This means that the SD contents are adequately included in the study programs. The chi-square statistic shows that the level of the study is moderately statistically significant positive correlated $(p<0.0000$; $V=0.465)$ to question regarding learning about SD. In comparison to the results from the study year $2011 / 2012$ (30\%), in this study the percentage of affirmative answers of first-year geography students of first level is much higher (58\%), which might draw us to the conclusion that the SD contents have found its place also in the curricula of secondary schools. For $10 \%$ is also higher the ratio of affirmative answers among third-year students of first level (2011/2012 86\%) (Kovačič in Brečko Grubar 2016), which somewhat confirms our assumptions that more attention has been drawn in geography study programmes in Slovenia to the contents of SD in recent period.

For Slovenian students of geography, "formal education " $(20 \%)$ is the most important source of knowledge about SD; this option was ticked off by as many as $86 \%$ of those who had already received some education about SD. This testifies that the SD contents are adequately integrated both in the formal education at the undergraduate and postgraduate study programmes of geography in Slovenia and in the curricula of secondary schools. The latter fact can be deduced from the answers by the first-year geography students. The importance of formal education for acquiring knowledge about SD in the undergraduate and postgraduate study programmes of geography is also manifest in the increasing percentage of answers in this category from the beginning of study at the undergraduate level to the postgraduate study. The research performed among the geography students in study year 2011/2012 (Kovačič and Brečko Grubar 2016) and the research performed among the students of several faculties of the UP (Kovačič and Brečko Grubar 2012) gave a similar result: formal education is the most important source of knowledge about SD. From the second to fourth place, follow documentary programmes (16\%), professional and scientific literature (13\%), internet sites, forums (13\%), papers and magazines $(11 \%)$.

The lowest percentage of answers by geography students from the three universities occurs within the category »informal education « (7\%), which encompasses students' activities in various courses, societies, workshops and round tables outside the regular study process. It shows the lack of students' interest for gaining SD knowledge outside the formal forms of education and mass media. Through active participation, various forms of informal education are a very suitable way of promotion of the SD guidelines, and young educated people should be the propelling power in this direction; however, the results show that this is not the case. Therefore, the role of teachers is very important at all levels of education, and at faculties in particular; it is teachers that should encourage zeal in the students for creating a better future by means of informing the public about the pressing necessity for the society to live and act in accordance with the SD principles. It is a miscalculation to rely merely on the self-initiative of the young in their assuming the responsibility.

The computed chi-square test shows that there are no statistically significant deviations in the answers regarding knowledge of SD between geography study programmes of the three Slovenian universities and year and level of the study.

$41 \%$ of students marked that the connectedness of the contents of Slovenian geography study programmes with SD is moderate, which is around $7 \%$ more that it was established in the former study (Kovačič and Brečko Grubar 2016). Statistically significant correlation between the connectedness of the contents of Slovenian geography study programmes with SD and university, year and level of the study and gender was not established. A variable connectedness of the content of SD with geography study programmes is low statistically significant positive correlated to the students own perception of knowledge of SD $(\rho=0.312 ; p<0.0000)$ and with the assessment of importance of SD for students $(\rho=0.284$; $p=0.0002$ ). This means that those students, who assessed their knowledge of SD being higher, simultaneously think that SD is more important and that its contents is more incorporated into theirs' study.

In order to establish the connectedness of Slovenian geography study programmes with the SD contents we asked the students to name up to five courses in the order of the amount of SD contents included 
in them. Included in further analyses were only the first three named courses, which, according to the opinion of the respondents, deal with the SD themes.

The UP geography students most often named as their first three selections the following courses: Sustainable Management of Water Resources (13\%), thus ranking first, next comes Hydrogeography and Geography of the Seas (10\%), ranking third are six courses (7\% each). The eight courses together account for $64 \%$ of the choices by the UP geography students. Most often named as their first selection were Introduction to Human Geography, second comes Karst Hydrology and Ecology, Economic and Social Geography and the third were Hydrogeography and Geography of the Seas and Development Challenges on Karst.

From among the first three selected courses, Ecological Geography (18\%), Economic Geography (16\%), Sustainable Water Resources Management (9\%) and Ecoremediation (9\%) was most often named by the UM geography students. The eight courses together account for $78 \%$ of the courses named by the UM geography students. As their first selection, they most often named Economic Geography, as the second Economic Geography, Ecological Geography and Ecoremediation, as the third ones again Ecological Geography.

The analysis of the stated titles of the courses shows that the UL geography students most often named as their first three selections the following ones: Geography of Sustainable Development (19\%), followed by Ecological Geography (18\%) and Human Ecology (16\%). The first four courses represent $67 \%$ and eight courses together $81 \%$ of all course titles named by the UL geography students. The UL students of geography most often named Geography of Sustainable Development (44\%) as their first selection among the courses; Human Ecology came as the second (30\%), and Geography of Natural Resources (18\%) as the third selected course.

From the results of the present and previous studies, we can conclude that geography study programmes of all three public universities in Slovenia put much consideration to the sustainable development themes and the progress in this field is evident. We can certainly hope that with the students' knowledge, sustainable development will find its proper position also in everyday lives. 